\title{
Facile Synthesis and Structural Characterization of Some Phthalazin- 1(2H)-one Derivatives as Antimicrobial Nucleosides and Reactive Dye
}

\author{
M.A.EL-Hashash ${ }^{1}$, S.A. Rizk ${ }^{1 *}$,F.A. El-Bassiouny ${ }^{1}$, D.B. Guirguis ${ }^{1}$,S. M. Khairy ${ }^{2}$, L.A.Guirguis ${ }^{2}$ \\ ${ }^{1}$ Department of Organic Chemistry, Faculty of Science, University of Ain Shams and \\ ${ }^{2}$ Department Of Reactor Materials , Nuclear Material Authority, Cairo, Egypt.
}

\begin{abstract}
NEW series of 2,4-disubstituted phthalazin-1(2H)-one derivatives were synthesized via nucleophilic attach of $\mathrm{N}-2$ of phthalazin-1(2H)-one derivatives on different monosuccharides. Synthesis of phthalazinone nucleosides were very effective as antimicrobial. Also the phthalazinone moiety can be used in synthesis of reactive nucleosides and dyes that were chemically bonded with proteins and fibers respectively as afforded highly stability of dyestuff wool and cotton textiles. The structure of the prepared compounds was elucidated by physical and spectral data like FT-IR, ${ }^{1} \mathrm{H}-$ and ${ }^{13} \mathrm{C}-\mathrm{NMR}$.
\end{abstract}

Keywords:Phthalazin-1 (2H) one, Allyl-, Propargyl - Phthalazinone, Epchlorohydrin, Nucleosides, Reactive dye

\section{Introduction}

Phthalazines as N-heterocycles have received considerable attention in the literature as a consequence of their exciting biological properties and their role as pharmacophore [1]. Some of phthalazinones were screened in vitro for their antimicrobial activity. The energy gap between HOMO and LUMO has been calculated to reflect the chemical reactivity and kinetic stability of compounds [2]. A Novel series of N-substituted-4-phenylphthalazin-1-ones bearing different anilines at the N-2 of phthalazin-1-one scaffold via acetyl-flexible linker as anticancer agents with the compounds were synthesized by insertion of methylene $\left(\mathrm{CH}_{2}\right)$ bridge at $\mathrm{C} 4$-position of phthalazinone moiety to provide a flexibility that increase their anti-proliferative activity against three human tumor cell [3]. Similarly, heterocycles containing the phthalazine moiety are of interest because they show some pharmacological and biological activities [4-6]. Phthalazine derivatives were reported to possess anticonvulsant [7], antitumor [8], antihypertensive [9], antithrombotic [10], antidiabetic [11], antitrypanosomal [12], anti-inflammatory [13], cardiotonic [14] and vasorelaxant activities [15]. Therefore, number of methods have been reported for the synthesis of phthalazine derivatives [16-22]. Despite the available methods, the development of new synthetic methods for the efficient preparation of phthalazinone derivative is therefore an interesting challenge. In addition phthalazinone and its derivatives were bis- phenol-like monomers which can be polymerized with the activated aryl dihalide monomers to give amorphous polymers [23] with high glass transition temperature and excellent thermo-stability, which are soluble in common organic solvents [23,24]. Recently [25-27] a series of poly(phthalazinone ether sulfone ketone(PPESK)) copolymers used as potential polymer in proton exchange membrane fuel cells[PEMFCs]. Corrosion of metals is a major industrial problem that has attracted many investgation and researchers [28,29]. The use of inhibitors is one of the most practical methods to protect metal against corrosion [30]. The adsorption on the metal surface depends mainly on the physicochemical properties of the inhibitor group, such as the functional group, molecular electronic structure and the molecular size [31-33]. Number of heterocyclic compounds containing nitrogen, oxygen and sulfur either in the aromatic or long chain carbon system have been reported to be effective inhibitors $[34,35]$. The planarity and the lone pair of electron in the hetero atoms are important features that determine the adsorption of molecules on the metallic surface [36]. The inhibition efficiency has been closely related to the inhibitor adsorption abilities and the molecular properties for different kinds of organic compounds $[37,38]$. The adsorption process depends on the electronic characteristic of the of organic molecules(adsorbate), and nature of the metal surface [39]. It may take place in the presence lone pair electrons of heteroatom ( $\mathrm{P}, \mathrm{Se}, \mathrm{S}, \mathrm{N}, \mathrm{O})$ and/or aromatic rings in the adsorbed molecules [40].

*Corressponding author e-mail: samehrizk@sci.asu.edu.eg
DOI :10.21608/EJCHEM.2017.915.1043

(C)2017 National Information and Documentation Center (NIDOC) 


\section{Results and Discussion}

In this article the authors could be reported [41] the synthesis of 4-( 3-chloro-4-methylphenyl)-1-(2H)phthalazinones 1 was obtained from ring closure of 3-chloro-4-methylphenyl benzoic acid using hydrazine hydrate (Scheme 1). Assignment of structures 1 could be based on correct IR, ${ }^{1} \mathrm{H}-\mathrm{NMR}$ and ${ }^{13} \mathrm{C}$-NMR spectroscopes and were listed in the experimental. The ester of phthalazin-1(2H)-one derivatives 2 was obtained by treatment of 1 with ethyl chloroacetate in the presence of anhydrous $\mathrm{K}_{2} \mathrm{CO}_{3}$ and dry acetone. The alkylation reaction takes place via $\mathrm{SN}^{2}$ mechanism and the role of anhydrous $\mathrm{K}_{2} \mathrm{CO}_{3}$ in pull of chloride ion as $\mathrm{KCl}$ and abstract of hydronium ion $\left(\mathrm{H}^{+}\right)$and converted to $\mathrm{KHCO}_{3}$. IR spectrum of 2 showed bands in the region $1649 \mathrm{~cm}^{-1}$ attributable to $v \mathrm{CO}$ of cyclic amide group in addition to $1750 \mathrm{~cm}^{-1}$ attributable to $v \mathrm{CO}$ of ester group, this indicate that the reaction takes place via $\mathrm{N}$-alkylation and not O-alkylation of the phthalazinone derivatives. In this investigation, the authors can be used to the hydrazide 3 a useful intermediate for construction of different heterocyclic compounds containing mixed and non-mixed systems. In this regard, the $(2 H)$ phthalazin1-one ring has attracted our attention in regard to synthesis of a hydrazide derivatives. Thus, when the phthalazin-1(2H)-one ester 2 was allowed to react with hydrazine hydrate in the presence of boiling ethanol yielded the corresponding the hydrazide 3 (Scheme 1).

Structure of hydrazide 3 was established on the basis of IR, 'H-NMR and elemental analysis data. IR spectrum exhibit two carbonyl groups for amide groups, which agreed well with the proposed structure. Synthesis of phthalazinone carrying electrophilic and nucleophilic sites were very effective to decrease the basicity of the hydrazide 3 to encourge in the stability of structure, for example in industrial binder of pigments i.e. $\mathrm{pH}$ doesn't change (the phthalazinone moiety is considered as chromophore) and as pro-drug to increase their biological activities. Also, the authors can be reported the ring closure of 3-chloro-4-methylphenyl benzoic acid using thiocarbonic dihydrazide. When 2-aroylbenzoic acid 1 was allowed to react with thiocarbonic dihydrazide under different solvent condition, afforded the new synthesized compounds 4, and 5 (Scheme 1). The reactions tookplace in a normal route to yielded the corresponding 2-phthalazinonyl thiohydrazide intermediate. The course of the reaction intermediate was depended upon solvent of the reaction. In polar aprotic solvent e.g. benzene, the reaction course tookplace intramolecular cyclization to yielded the corrosponded triazolethione derivative 4. But, in polar protic solvent condition e.g. ethanol, the reaction course tookplace intermolecular ring closure of the intermediate with another aroylbenzoic molecule, means 2 mole of 2-aroylbenzoic acid can be reacted with 1 mole of thiocarbonic dihydrazide, afforded the diphthalazinonyl thione 5 . the phthalazinone moiety considered as chromophore and play an important role in the field of the dying. It was characterized as synthesis of the reactive dye (Scheme 2), when it allowed to sulphonate with concentrated sulfuric acid, it was affording 6 to enhance the chromophoric moiety. Also, Glycosyl heterocycles and their nucleoside analogues have multiple potential applications. Significant progress with such analogues has let to advances in cancer chemotherapy and anti HBV and HIV applications. The lack of an effective therapy to treat hepatitis B virus and HIV infections, particularly in chronic cases has focused considerable effort into the synthesis of nucleoside analogues possessing antiviral activity [22-24]. Some analogues having either modified bases and/or glycosyl residues have shown promise in antiparasite chemotherapy $[25,26]$ for cytokinin activities [42,43] as antihypertensive agent [44], as biochemical tools $[45,46]$ and as inhibitors of cellular enzymes $[47,48]$. An area of intensive research is in the design of nucleoside analogues where in the a glycone moieties are altered while biological activity is retained. This type of novel design of nucleoside analogue pertains to modified nucleo-bases which are of neither the purine nor pyrimidine types. We have reported the synthesis and biological activity of nucleoside analogues incorporating modified nucleobases $[49,50]$. In this regard, the $(2 H)$ phthalazin-1-one ring has attracted our attention in synthesis of a cyclo-nucleoside derivatives. Thus, when the phthalazin-1(2H)-one derivatives 1 was allowed to react with $\alpha$-D-arabino- and/or glucopyranosyl bomide in the presence $\mathrm{K}_{2} \mathrm{CO}_{3} /$ dry DMF yield the corresponding $\mathrm{N}$-cyclonucleosides $2-(\alpha-\mathrm{D}$ arabino- and/or gluco-pyranosyl)-4-phenyl phthalazinone (7 and 8) respectively (Scheme 2). Structure of 7 and 8 were established on the basis of IR, ${ }^{1} \mathrm{H}-\mathrm{NMR}$ and elemental analysis data. IR spectrum exhibit carbonyl group for cyclic amide, which agreed well with the proposed structure. Moreover, Creation of the builder 9 , when the sulphonated phthalazinone 6 was allowed to react with 2,4,6-trichloro-1,3,5-triazine(TCT) in the presence of pyridine, it was afforded 9 that be ready reacted with the fibers. So, the phthalazinone moiety can be used in synthesis of reactive dyes that was chemically bonded with fibers as afforded highly stability of dying wool and cotton textiles. Assignments of structure 9 can be based on correct elemental analyses, IR, and ${ }^{1} \mathrm{H}$ NMR spectral data. Reactions of the phthalazinone 1 within preferred halide of amino acid to yield $\alpha$-amino acids carrying phthalazinone bases 10 

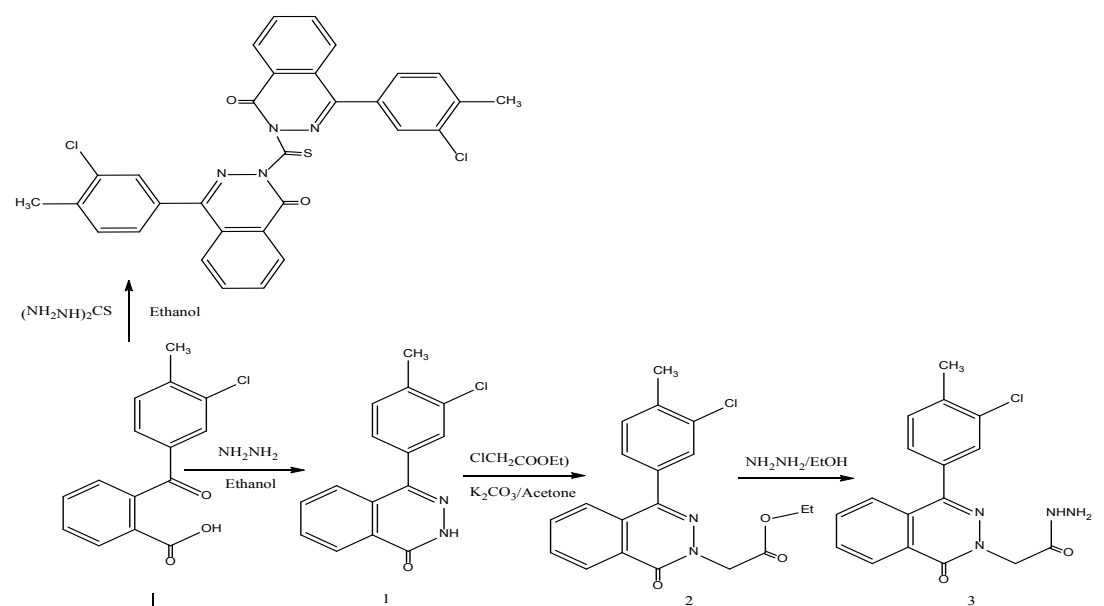<smiles>Oc1ccc(-c2nc3ccccc3c3cnc(Cl)nc23)cc1O</smiles>

Scheme 1

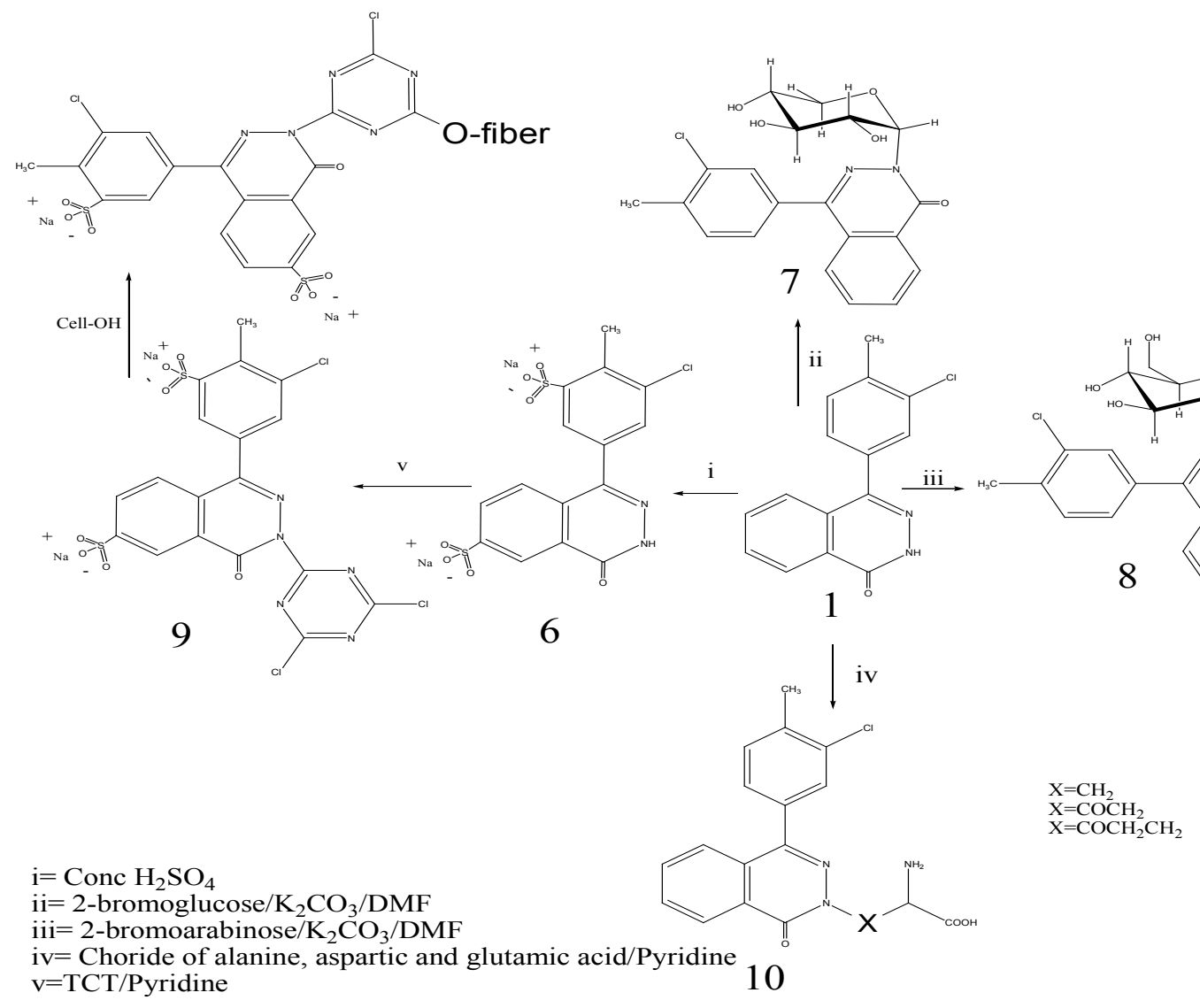

\section{Scheme2}


Reactions of the phthalazinone 1 within preferred halide of amino acid to yield $\alpha$-amino acids carrying phthalazinone bases 10 (Scheme 2). It's important to improve the amino acid in which as carrying a pro-drug precursor. A novel synthesized bases for protein that can be used for enzymatic reaction and drug delivery. When the phthalazinone 1 was allowed to react with halide of $\alpha$-amino acids e.g. $\beta$-chloroalanine, Aspartic and/or Glutamic acid monochloride, to yield the target compounds 10. Assignments of structures 10 are based on correct elemental analyses, IR and ${ }^{1} \mathrm{H}$ - NMR spectral data, the IR spectrum exhibits strong absorption bands at 1661-1665, 1684 and 1686 attributable to $v \mathrm{CO}$ , the ${ }^{1} \mathrm{HNMR}$ of compound 10 showed signals at $2.2\left(\mathrm{dt}, 1 \mathrm{H}, \underline{\mathrm{CH}}\left(\mathrm{NH}_{2}\right) \mathrm{COOH}\right)$ and 6.4 and $8.2(\mathrm{~s}$, $3 \mathrm{H}, \mathrm{NH}_{2}$ and $\mathrm{COOH}, \mathrm{D}_{2} \mathrm{O}$ exchangeable). The biological activities of the compounds 10 could be became more effective than the phthalazinone itself, and the reverse result occurred within the compounds 7 and 8 that can't be expected.

On the other hand, refluxing of [1(2H)-oxo4-(3-chloro-4-methylphenyl)phthalazin-2-yl] acetic acid hydrazide (3) with aromatic aldehydes e.g. 4-N,N-dimethyl aminobenzaldehyde and/ or 4-chlorobenzaldehyde in boiling ethanol afforded $\mathrm{N}$-arylidine derivatives 11 in good yields, the ${ }^{1} \mathrm{H}-\mathrm{NMR}$ spectrum of $11 \mathrm{a}$ exhibited at $\delta 8.75$ assigned for the methylidene proton, the mass spectrum of compound $11 \mathrm{~b}$ showed the ion peak at $\mathrm{m} / \mathrm{z} 570(48.46 \%)$ corresponding to $\mathrm{M}^{+}$. Repeating of the above reaction of hydrazide with 4-nitro-2-(2-aminothio phenyl)benzaldehyde, affording unexpected product of 1,3-thiazepino1,2,4-triazole 12 (Scheme 3). Moreover, when the hydrazide 3 was submitted to react with phthalaic anhydride and/or isatin in an oil bath at $150^{\circ} \mathrm{C}$, it yielded [4-(3-chloro 4-methyl-)phenyl1(2H)-oxo-phthalazin-2-yl]-N-phthalimidoacetamide 13 and/or indol-2-on-3-yl-acetyl hydrazone 14 respectively. IR spectrum of compounds 13 and 14 revealed strong absorption bands at the regions 1655,1690, 1735 and 1790 $\mathrm{cm}^{-1}$ attributable to $v$ (4CO), and 1660, 1670 and 1705 attributable to $v$ of $(3 \mathrm{CO})$ respectively.

The authors can be explained formation of dibenzothiazepinotriazole, when the hydrazide 3 was allowed to react with new carbon electrophile e.g ethyl-2-thiocyanatobenzoate in boiling ethanol affording an important species of 4-oxo-benzothiazino-1,2,4-triazole derivatives 15 . The reaction possibly proceeds according to the following mechanism (Scheme 4).

The ${ }^{1} \mathrm{H}-\mathrm{NMR}$ of compound. The authors can be reported synthesis and characterization, when the hydrazide 3 was allowed to react with new carbon electrophile e.g ethyl-2-thiocyanatobenzoate in boiling ethanol affording an important species of 4-oxo-benzothiazino-1,2,4-triazole derivatives 15 (Scheme 4). 15 showed signals at $\delta 4.75$ for $\mathrm{CH}_{2}$ of inserted between the two heterocyclic moieties. The mass spectrum of compound 15 showed the prominent ion peak at $\mathrm{m} / \mathrm{z} 491(2.25 \%)$ and $493(2.48 \%)$ attributable to $\mathrm{M}^{+}$and $\mathrm{M}^{+}+2$ respectively. To continue and enhancement the chromophoric moiety, when the phthalazinone hydrazide derivative 3 was allowed to react with alkyl- and/or aryl-isothiocyanate namely methyl, ethyl, cyclohexyl, and phenyl isothiocyanate afforded thiocarbamate [51, 52]. But in one pot reaction, when the hydrazide 3 was allowed to react with 2-glucosyl bromide and ammonium isothiocyanate afforded the novel N-nucleoside 16. The reaction could be formed glucosyl isothiocyanate intermediate via mixed the glycosyl bromide with ammonium isothiocyanate that can be scavenged by the hydrazide derivative 3 to afford the target compounds 16 that its structure was verified by spectral tools. (Scheme 4). The ${ }^{1} \mathrm{H}-\mathrm{NMR}$ of compound 16 exhibited signal at $\delta$ 5.7 and 9.90 assigned for $5 \mathrm{H}$ of $\mathrm{OH}$ and $\mathrm{NH}$ that both are $\mathrm{D}_{2} \mathrm{O}$ exchangeable. The phthalazinone moiety that incorporated with triazole and/or thiadiazole moieties 15 and 16 can be also flexible and used in synthesis of anticancer agents.

\section{Antimicrobial evaluation}

Compounds 1, 2, 3, 4, 5, 6, 7, 8, and 10 were tested for antimicrobial activity against Escherichia coli (Gram negative bacterium), Staphylococcus aureus (Gram positive bacterium), Aspergillus flavus and Candida albicans (fungi) using the disc diffusion method. The antimicrobial evaluation was done in the Microanalytical Center at Cairo University

\section{Generaldiscdiffusion(agarbased)method}

Standard discs of tetracycline (antibacterial agent) and amphotericin B (antifungal agent) served as positive controls and references for antimicrobial activities respectively, but filter discs impregnated with $10 \mu \mathrm{L}$ of solvent (chloroform, ethanol, DMF) were used as a negative control. The agar used is Mueller - Hinton agar that

Egypt.J.Chem. 60 , No.3 (2017) 


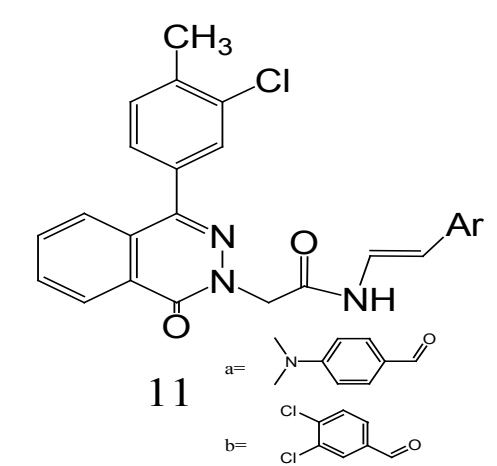<smiles>Cc1ccc(-c2nn(C3=NNC4c5cc([N+](=O)[O-])ccc5Sc5ccccc5N34)c(=O)c3ccccc23)cc1Cl</smiles>

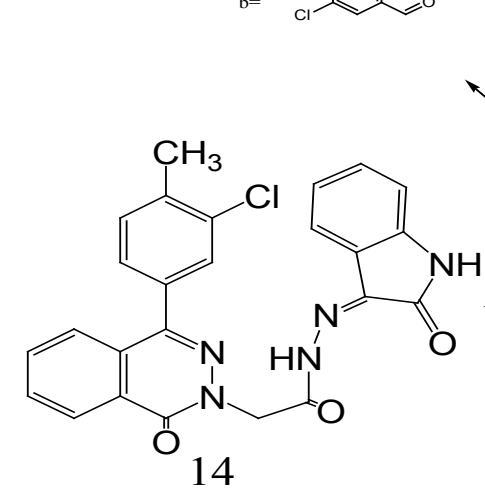

14<smiles>C#CC#CC1=NN(CC(N)NN)C(O)c2ccccc21</smiles>

$\mathrm{i}=$ Phthalic anhyride/fuse ii $=$ Isatan/fuse $\mathrm{iii}=\mathrm{Ar}{ }^{-} \mathrm{CHO} /$ Ethanol

Scheme3

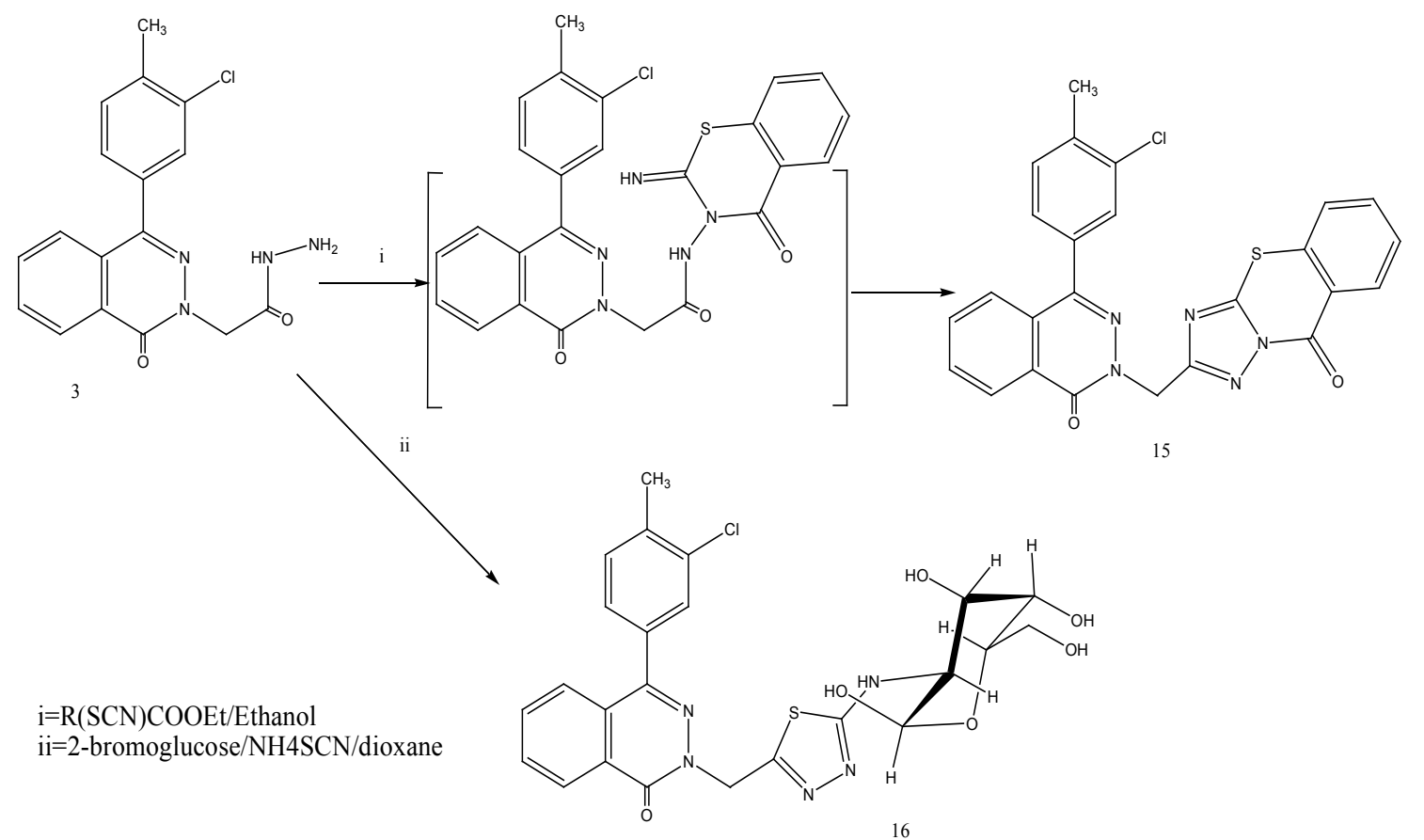

Scheme 4 
is rigorously tested for composition and $\mathrm{pH}$. The depth of the agar in the plate is a factor to be considered in this method. Blank paper discs (Schleicher and Schuell, Spain) with a diameter of $8.0 \mathrm{~mm}$ were impregnated with $10 \mu \mathrm{L}$ of the tested concentration of the stock solutions. When a filter paper disc impregnated with a tested chemical is placed on agar, the chemical will diffuse from the disc into the agar. This diffusion will place the chemical in the agar only around the disc. The solubility of the chemical and its molecular size will determine the size of the area of chemical infiltration around the disc. If an organism is placed on the agar it will not grow in the area susceptible to the chemical around the disc. This area of no growth around the disc is the "zone of inhibition" or "clear zone". For disc diffusion, the zone diameters were measured with slipping calipers of the National Committee for Clinical Laboratory Standards (NCCLS) [20]. Agar-based method is a good alternative method being simpler and faster than brothbased methods [21, 22]. It's well-known that $\mathrm{N}$-nucleosides could be preferred as a bioactive molecule, but a negative result occurred. Table 1 outlined the results of biological activity of the compounds 1, 6,7,10a,10b, and 10c. Otherwise, the importance of presence the acetyl group in the derivatives $10 \mathrm{~b}$ and $10 \mathrm{c}$, the felexibility of the target for matching with piptide structures that can be used to destruct the tumer cell formed.

\section{Antibacterial Activity}

Concentration of $1 \mathrm{mg} / \mathrm{mL}$ of test compounds were prepared by dissolving the compounds in its proper solvent. For each concentration, $0.2 \mathrm{~mL}$ of synthesized compounds ( $1 \mathrm{mg} / \mathrm{mL})$ was added to each hole. The plates were allowed to stand at room temperature for two hours and then incubated. The organisms were grown in nutrient agar at $37^{\circ} \mathrm{C}$ for 24 hours. After incubation period, the growth inhibition zones diameters were carefully measured in $\mathrm{mm}$. The clear zone around the wells was measured as inhibition zones. The absence of a clear zone around the well was taken as inactivity.

Results of antibacterial activity tested against E. Coli $\left(\mathrm{G}^{-}\right)$and $S$. Aureus $\left(\mathrm{G}^{+}\right)$showed that all of the selected compounds were antibacterially active and comparatively efficient.

\section{Antifungal Activity}

The samples were dissolved, each in its proper solvent, then $0.5 \mathrm{~mL}$ sample of each compound
( $1 \mathrm{mg} / \mathrm{mL}$ ) plus $0.1 \mathrm{~mL}$ of the tested fungal suspension were mixed thoroughly with $20 \mathrm{~mL}$ of agar medium, which was maintained at $45^{\circ} \mathrm{C}$. The inoculated medium was poured into sterile Petri-dishes, allowed to solidify, and incubated at $25^{\circ} \mathrm{C}$ for seven days. Results of antifungal activity tested showed that compounds 2, 3, 6, 10a and 10b were active against both fungi, none was active with A. flavus, 4, 5, 8 and 10c were active only with C. albicans, whereas the rest of compounds were totally inactive. All the results for the antimicrobial evaluation are given in (Table 1) showing the inhibition zone diameter in $\mathrm{mm} / \mathrm{mg}$ sample. Both compounds 3 , and 6 showed the highest inhibition with $S$. aureus whereas compounds 3, 6 and 10 showed the highest inhibition towards $C$. albicans.

In conclusion all the products $1,2,3,4,5,6,7$, $8,10 \mathrm{a}, 10 \mathrm{~b}$, and $10 \mathrm{c}$ were antibacterially active and comparatively efficient. In addition, compounds 2 , $3,6,10 \mathrm{a}$ and $10 \mathrm{~b}$ were active against both fungi, 4 , 5 , and $10 \mathrm{c}$ were active only with C. albicans, and the rest were inactive.The antimicrobial activity of the products compared to those of tetracycline (TC) and amphotericin B (ATB) are given in Fig 1 ..

\section{Conclusion}

The aim of this work is synthesis of some important phthalazinone derivatives to study influence of the molecular structure on the inhibiting efficiencies of organic compounds in E. Coli, S. Aureus, P. Flavus, and C. Albicans. Nitrogen based compounds are effective antibacterial (Staph.aureus and Escherichia coli), and antifungal activities( Pseud. flavus and Candida albicans). It's found the presence of lone pair of electrons on the nitrogen atom of the additional atom delocalized and thus produce a delocalization energy that stabilized the phthalazinone compounds. The investigated phthalazine derivatives have been shown inhibiting properties for antimicrobial reagents. The structure and composition of most of synthesized phthalazine derivatives can be influence their inhibiting efficiency for microbes.

\section{Experimental}

Melting points are corrected. IR spectra $(\mathrm{KBr}$ disc) were recorded on infrared spectrometer FT-IR 400D (Perkin-Elmer) spectrophotometer. ${ }^{1} \mathrm{H}-\mathrm{NMR},{ }^{13} \mathrm{C}-\mathrm{NMR}$ spectra are recorded on a varian $200 \& 500 \mathrm{MHz}$ and avarian $300 \mathrm{MHz}$. All chemical shifts were reported as $(\delta)$ ppm scale using 
TABLE 1. In vivo antimicrobial activity by agar diffusion method of tested compounds Inhibition zone diameter (mm / mg sample)

\begin{tabular}{lccccc} 
Compound & E. coli & S. aureus & A. flavus & C. albicans & Control solvent \\
\hline Tetracycline TC & 32 & 35 & 00 & 00 & ---- \\
Amphotericin B & 00 & 00 & 18 & 20 & ---- \\
1 & 11 & 10 & 00 & 00 & Chloroform \\
2 & 07 & 12 & 07 & 12 & DMF \\
3 & 16 & 16 & 12 & 15 & Ethanol \\
4 & 14 & 17 & 00 & 14 & Ethanol \\
5 & 15 & 16 & 00 & 14 & Ethanol \\
6 & 16 & 17 & 16 & 15 & Ethanol \\
7 & 09 & 09 & 00 & 00 & Chloroform \\
8 & 13 & 13 & 00 & 11 & Ethanol \\
$10 \mathrm{a}$ & 08 & 21 & 09 & 17 & Ethanol \\
$10 \mathrm{~b}$ & 08 & 21 & 09 & 17 & Ethanol \\
$10 \mathrm{c}$ & 13 & 17 & 00 & 17 & Ethanol \\
\hline
\end{tabular}

TMS as internal standard and coupling constant values are given in Hz. Elemental analyses were carried out at the Microanalytical Center,National Research Center, Cairo university, Giza, Egypt

\section{4-(3-Chloro-4-methylphenyl)phthalazin-1(2H)-} one (1)

Hydrazine hydrate $(0.015 \mathrm{~mol})$ was added to a solution of 3-chloro-4-methylphenyl benzoic acid $(0.01 \mathrm{~mol})$ in absolute ethanol and the reaction mixture was heated under refluxed for 3h. The solid that separated after cooling was filtered off and recrystallized from ethanol to give the phthalazinon 2, 80\% yield as colorless crystals, m.p. $220-222{ }^{\circ} \mathrm{C}$; The ${ }^{1} \mathrm{H}-\mathrm{NMR}$ spectrum showed signal at 2.35 (methyl group), $7.3-7.7$ (m, 7H, ArH ) , $10.5(\mathrm{~s}, 1 \mathrm{H}, \mathrm{NH}$, exchangeable with $\left.\mathrm{D}_{2} \mathrm{O}\right)$. IR (KBr) $v \mathrm{~cm}^{-1}: 3296(\mathrm{NH}), 1665$ $(\mathrm{C}=\mathrm{O}), 1605(\mathrm{C}=\mathrm{N})$. Ms: $m / z: 276\left(\mathrm{M}^{+}, 100\right)$, 248 (43), 220 (15), 131 (25), 105 (15). Anal calcd for $\mathrm{C}_{15} \mathrm{H}_{11} \mathrm{~N}_{2} \mathrm{O} \mathrm{Cl}(270)(\%)$ : C, 66.66; $\mathrm{H}$, 4.07; N 10.37; found $\mathrm{C}, 66.45$; H 4.02; N 10.12

\section{Ethyl2-(1-oxo-4-(3-chloro-4-methylphenyl)phthalazine- 2(1H)-yl)acetate (2)}

A mixture of compound 1 (0.01 mol), $5 \mathrm{~mL}$ ethylbromoacetate, and $4.1 \mathrm{~g}$ anhydrous $\mathrm{K}_{2} \mathrm{CO}_{3}$ $(0.03 \mathrm{~mol})$ in dry acetone $(30 \mathrm{~mL})$ was heated under reflux for $24 \mathrm{~h}$. The solvent was evaporated and the residue was diluted with water, the solid obtained was filtered off, dried and crystallized from pet.ether $\left(80-100^{\circ} \mathrm{C}\right)$. Yield $84 \%$ as white crystals. m.p. $110-112^{\circ} \mathrm{C}$. IR $(\mathrm{KBr}) v \mathrm{~cm}^{-1}: 1750$, $1649(\mathrm{C}=\mathrm{O}), 1584(\mathrm{C}=\mathrm{N}) ;{ }^{1} \mathrm{H}-\mathrm{NMR}\left(\mathrm{DMSO}_{-} \mathrm{d}_{6}\right)$ $\delta$ ppm: 1.27 (t, J=7.2 $\left.\mathrm{H}_{7}, 3 \mathrm{H}, \mathrm{CH}_{2} \underline{\mathrm{CH}}_{3}\right), 2.14$ (s, $\left.3 \mathrm{H}, \mathrm{CH}_{3}\right), 4.12\left(\mathrm{q}, \mathrm{J}=7.5 \mathrm{H}_{\mathrm{Z}}, 2 \mathrm{H}, \mathrm{O}_{2} \mathrm{CH}_{3}\right), 5.3$ (s, 2H, $\left.\mathrm{CH}_{2}\right), 7.3-7.7$ (m, 7H, Ar-H). Ms : m/z 362 $\left(\mathrm{M}^{+}, 78 \%\right), 290$ (100\%), 134 (22\%), 77 (39\%). Anal calcd for $\mathrm{C}_{19} \mathrm{H}_{17} \mathrm{~N}_{2} \mathrm{O}_{3} \mathrm{Cl}(356)(\%)$ : C, 64.04; H, 5.05; N, 7.86; found C, 64.01; H, 5.01; N, 7.66.

2-(1-Oxo-4-(3-chloro-4-methylphenyl) phthalazine2(1H)-acetohydrazide (3)

A mixture of 2 (4.01g) and hydrazine hydrate (2 $\mathrm{mL})$ in boiling ethanol $(50 \mathrm{~mL})$ was refluxed $1 \mathrm{~h}$ and cooled at room temperature. The solid that formed was filtered off, dried and crystallized from ethanol. Yield 78\%. Off white crystal. $\mathrm{Mp} 160-162^{\circ} \mathrm{C}$. IR(KBr) $v \mathrm{~cm}^{-1}: 1658(\mathrm{C}=\mathrm{O})$, $3324,3417\left(\mathrm{NHNH}_{2}\right) . \quad{ }^{1} \mathrm{H}-\mathrm{NMR} \quad$ (DMSO-d6) $\delta$ ppm: $1.8\left(\mathrm{~m}, 3 \mathrm{H}, \mathrm{CH}_{3}\right), 4.26\left(\mathrm{~s}, 2 \mathrm{H}, \mathrm{NH}_{2}\right.$ exchangeable protons with $\left.\mathrm{D}_{2} \mathrm{O}\right), 4.76(\mathrm{~s}, 2 \mathrm{H}$, $\left.\mathrm{CH}_{2} \mathrm{CO}\right), 7.53-8.64(\mathrm{~m}, 7 \mathrm{H}, \mathrm{Ar}-\mathrm{H}), 8.4(\mathrm{~s}, 1 \mathrm{H}$, $\mathrm{NH}$ exchangeable with $\left.\mathrm{D}_{2} \mathrm{O}\right) .13 \mathrm{C} \mathrm{NMR}\left(\mathrm{CDCl}_{3}\right)$ $\delta$ ppm: 171.5, 159.7, 139.6,.139.5, 135.9, 13 $5.7,133.5,132.5,132.5,2.4,130.5,129.3,129.3$ ,127.6,127.6,127.2,55.6, and15.2 (CS) Anal. Calc. for $\mathrm{C}_{17} \mathrm{H}_{15} \mathrm{~N}_{4} \mathrm{O}_{2} \mathrm{Cl}(343)(\%) \mathrm{C} 59.47, \mathrm{H}$ 4.66, N 16.32; found C 59.23, H 4.23, N 16.26.

(3-Chloro-4-methylphenyl)-[1,2,4]triazolo[3,4-a] phthalazine -3(2H)thione (4)

Thiocarbonic dihydrazide $(0.015 \mathrm{~mol})$ was added to a solution of phthalazinone $1(0.01 \mathrm{~mol})$ in 
benzene $(30 \mathrm{~mL})$ and the reaction mixture was heated under refluxed for $3 \mathrm{hr}$. The solid that separated after cooling was filtered off and recrystallized from benzene to give $4,80 \%$ yield as colorless crystals, m.p. 164-166 ${ }^{\circ}$; IR (KBr) $v \mathrm{~cm}^{-1}: 3296(\mathrm{NH}), 1605(\mathrm{C}=\mathrm{N})$, $1115(\mathrm{C}=\mathrm{S}) \quad{ }^{1} \mathrm{H}-\mathrm{NMR}$ (DMSO-d6) $\delta \mathrm{ppm} 2.35(\mathrm{~m}$, $\left.3 \mathrm{H}, \mathrm{CH}_{3}\right), 7.3-7.7$ (m, 7H, ArH ), 11.2 (s, 1H, NH, exchangeable with $\left.\mathrm{D}_{2} \mathrm{O}\right)$. Ms: $\mathrm{m} / \mathrm{z} 332\left(\mathrm{M}^{+}, 100 \%\right), 248$ $(43 \%), 220(15 \%), 131(25 \%), 105(15 \%)$. Anal calcd for $\mathrm{C}_{16} \mathrm{H}_{11} \mathrm{~N}_{4} \mathrm{~S} \mathrm{Cl}(326)(\%)$ : C, 58.89; H, 3.37; N, 17.17 ; S, 9.81 ; found C, 57.57 ; H, $3.52 ; \mathrm{N}, 17.70 ; \mathrm{S}, 9.67$.

Thiocarbonylbis(4-(3-chloro-4-methylphenyl) phthalazin) -1 (2H)-one (5)

Thiocarbonic dihydrazide $(0.015 \mathrm{~mol})$ was added to a solution of phthalazinone 1 (0.01 $\mathrm{mol})$ in absolute ethanol $(30 \mathrm{~mL})$ and the reaction mixture was heated under refluxed for $3 \mathrm{~h}$. The solid that separated after cooling was filtered off and recrystallized from ethanol to afford 5, 80\% yield as colorless crystals, m.p. $210-212{ }^{\circ} \mathrm{C}$; The IR $(\mathrm{KBr}) v \mathrm{~cm}^{-1}: 3296(\mathrm{NH}), 1665(\mathrm{C}=\mathrm{O}), 1605$ $(\mathrm{C}=\mathrm{N}) .{ }^{1} \mathrm{H}-\mathrm{NMR}$ (DMSO-d6) $\delta \mathrm{ppm}$ at $2.2(\mathrm{~m}$ ,6H, 2 $\left.\mathrm{CH}_{3}\right), 7.1-7.9(\mathrm{~m}, 14 \mathrm{H}, \mathrm{ArH}), 9.5(\mathrm{bs}, 1 \mathrm{H}$, NH). Ms : m/z $594.72\left(\mathrm{M}^{+}, 100 \%\right), 248(43 \%)$, $220(15 \%), 131$ (25\%), 105 (15\%). Anal calcd for $\mathrm{C}_{31} \mathrm{H}_{20} \mathrm{~N}_{4} \mathrm{O}_{2} \mathrm{~S} \mathrm{Cl}_{2}(550)(\%): \mathrm{C}, 63.91 ; \mathrm{H}, 3.43 ; \mathrm{N}$, 9.62; S, 5.49; found C, 63.6; H3.23; N, 9.1; S, 5.52.

Sodium-4-oxo-1-(5-sulfonato-3-chloro-4methylphenyl)-3,4-dihydrophthalazine-6sulfonate (6).

Sulphonation of phthalazinone $1(2.2 \mathrm{~g} ; 0.01$ mol) with concentrated $\mathrm{H}_{2} \mathrm{SO}_{4}(0.02 \mathrm{~mol})$ was heated under reflux 30 min., and then pour prohibition and slowly the reaction mixture upon solution of concentrated $\mathrm{Na}_{2} \mathrm{CO}_{3}$. Yield $80 \%$. $\mathrm{Mp}=184-186{ }^{\circ} \mathrm{C}$. IR (KBr) $v \mathrm{~cm}^{-1} 1650$ (amide) (CO), 1592-1519 ( $\mathrm{SO}_{3}$ ). ${ }^{1} \mathrm{H}-\mathrm{NMR}$ (DMSO-d6) $\delta$ ppm at $2.28\left(\mathrm{~m}, 6 \mathrm{H}, 2 \mathrm{CH}_{3}\right), 7.67-8.28(\mathrm{~m}, 6 \mathrm{H}$, Ar-H), . Anal. Calc. for $\mathrm{C}_{15} \mathrm{H}_{9} \mathrm{~N}_{2} \mathrm{Na}_{2} \mathrm{~S}_{2} \mathrm{O}_{7} \mathrm{Cl}_{2}$ (421) (\%): C ,40.00; H ,2.0; N, 6.22; S, 14.22; found: C, 39.89; H, 2.12, N, 6.08; S, 14.09.

2-( $\alpha$-D-Arabinopyranosyl)-4-phenylphthalazinone (7) and 2-( $\alpha$-D-gluco-pyranosyl)-4-phenyl phtha- lazinone (8)

A mixture of 1 (2.2g; $0.01 \mathrm{~mol}), 1$-bromo- $\alpha$-Darabinopyranose and/or 1-bromo- $\alpha$-D-glucopyranose $(0.01 \mathrm{~mol})$ and anhydrous $\mathrm{K}_{2} \mathrm{CO}_{3}(3 \mathrm{~g} ; 0.02 \mathrm{~mol})$ in dry DMF $(30 \mathrm{~mL})$ was stirring at room temperature $24 \mathrm{~h}$. The excess solvent was evaporated under reduced pressure and the reaction mixture was diluted with water. The solid that obtained was crystallized from dioxane

(4-(3-Chloro-4-methylphenyl)-2-((2S,3R,4R, 5S,6R)3,4,5-trihydroxy-6-(hydroxymethyl)tetrahydro- $2 \mathrm{H}$ pyran2-yl)phthalazin-1(2 H)-one(7)

Yield 90\%. Mp 150-1520 C.IR (KBr) $v \mathrm{~cm}^{-1} 1652$ (amide) (CO). ${ }^{1} \mathrm{H}-\mathrm{NMR}$ (DMSO-d6) $\delta \mathrm{ppm}$ at 2.39 $\left(\mathrm{m}, 3 \mathrm{H}, \mathrm{CH}_{3}\right), 2.22-2.39(\mathrm{~m}, 6 \mathrm{H}, \mathrm{H}$ of arabinose moiety), 4.36-4.51(m, 3H, OH), 7.46-8.23 (m, 7H, Ar-H). Anal. Calc. for $\mathrm{C}_{20} \mathrm{H}_{19} \mathrm{~N}_{2} \mathrm{O}_{6} \mathrm{Cl}(354)$ : C, 57.69; $\mathrm{H}, 4.08$; N, 6.73; found: C, 57.21, H, 4.32; N ,6.51.

(4-(3-Chloro-4-methylphenyl)-2-((2S,3R,4R, 5S,6R)2,3,4,6-tetrahydroxy-6-(hydroxymethyl) tetrahydro-2Hpyran2-yl)phthalazin-1(2H)-one (8)

Yield $90 \%$. Mp $170-172^{\circ} \mathrm{C}$ IR $(\mathrm{KBr}) v \mathrm{~cm}^{-1}: 1652$ (amide) (CO). ${ }^{1} \mathrm{H}-\mathrm{NMR}$ (DMSO-d6) $\delta$ ppm at: 2.33 $\left(\mathrm{m}, 3 \mathrm{H}, \mathrm{CH}_{3}\right), 2.12-2.62(\mathrm{~m}, 7 \mathrm{H}, \mathrm{H}$ of glucose moiety), 4.36-4.51(m, 4H, OH), 7.46-8.23 (m, 7H, Ar-H). Anal. Calc. for $\mathrm{C}_{21} \mathrm{H}_{21} \mathrm{~N}_{2} \mathrm{O}_{6} \mathrm{Cl}(464)$ : C, 58.74; $\mathrm{H}, 4.89$; N, 6.52; found: C, 58.33, H, 4.46; $\mathrm{N}, 6.24$

Sodium-3-(4,6-dichloro-1,3,5-triazin-2-yl)-4oxo-1-(5-sulfonato-3-chloro-4-methylphenyl)3,4-dihydrophthalazine-6-sulfonate (9)

A mixture of phthalazinone disulphonated (0.01 $\mathrm{mol})$ and 2,4,6-trichlorotriazine $(0.01 \mathrm{~mol})$ in pyridine and refluxing for $2 \mathrm{~h}$. Pour the reaction mixture after cooling on petroleum ether. Teatment the aqueous layer with conc. $\mathrm{HCl}$. Filter the solid product 9 in the acid form. Yield $80 \%$. $\mathrm{Mp}=234-236{ }^{\circ} \mathrm{C}$. IR (KBr) $v \mathrm{~cm}^{-1}: 1650$ (amide) (CO), 1592-1519( $\left.\mathrm{SO}_{2}\right) .{ }^{1} \mathrm{H}-\mathrm{NMR}$ (DMSO-d6) $\delta$ ppm at: $2.4\left(\mathrm{~m}, 3 \mathrm{H}, \mathrm{CH}_{3}\right), 7.67-8.28(\mathrm{~m}, 7 \mathrm{H}$, Ar-H). Anal. Calc. for $\mathrm{C}_{18} \mathrm{H}_{8} \mathrm{Cl}_{3} \mathrm{~N}_{5} \mathrm{Na}_{2} \mathrm{~S}_{2} \mathrm{O}_{7}(597)$ : C ,36.18; H, 1.34; N 11.72; S, 10.72 found: $\mathrm{C}$ ,36.06; H , $1.2 ;$;N, 11.8; S, 10.37

Synthesis of phthalazinone amino acids 10

A mixture of compound 1 (0.01 mol), chloride of $\alpha$-amino acids namely; $\beta$-chloroalanine, 2 -amino-4chloro-4-oxobutanoic acid (chloride of aspartic), and 2-amino-5-chloro-5-oxobutanoic acid (chloride of glutamic) in pyridine $(30 \mathrm{~mL})$ and few drops of water was heated under reflux for $4 \mathrm{~h}$. The solvent was evaporated and the residue was diluted with water, the solid obtained was filtered off, dried and crystallized from pet.ether $\left(80-100^{\circ} \mathrm{C}\right)$.

2-Amino-3-(1-oxo-4-(3-chloro-4-methylphenyl) phthalazin-2(1H)-yl) propanoic acid (10a)

Yield $84 \%$ as white crystals. Mp $210-212{ }^{\circ} \mathrm{C}$. IR (KBr) $v \mathrm{~cm}^{-1}:$ 1751, 1658(CO). ${ }^{1} \mathrm{H}-\mathrm{NMR}$ (DMSO-d6) $\delta$ ppm at: $2.35\left(\mathrm{~m}, 3 \mathrm{H}, \mathrm{CH}_{3}\right), 4.14-4.19(2 \mathrm{dd}, 2 \mathrm{H}$, $\left.\mathrm{CH}_{2} \mathrm{~N}\right), 4.56(\mathrm{dd}, 1 \mathrm{H}, \mathrm{CH}), 5.6\left(\mathrm{bs}, 2 \mathrm{H}, \mathrm{NH}_{2}\right), 7.33-8.28$

Egypt.J.Chem. 60 , No.3 (2017) 
(m, 7H, Ar-H ), 8.3(s, 1H, COOH). ${ }^{13} \mathrm{C} \mathrm{NMR}\left(\mathrm{CDCl}_{3}\right)$ $\delta$ ppm: 33.6(CH2), $53.8(\mathrm{~N}-\mathrm{CH} 2), 20.6,53.3,127.2$, $127.5,127.6,129.2,129.3,130.5,130.9,132.2,132$. 3.133.3.134.7.134.5,138.3,158.0(C=N), and 172.8 $(\mathrm{C}=\mathrm{O})$ Anal. Calc for $\mathrm{C}_{18} \mathrm{H}_{16} \mathrm{~N}_{3} \mathrm{O}_{3} \mathrm{Cl}(357) \mathrm{C}, 60.50 ; \mathrm{H}$ ,4.48; N, 11.76 ; found $\mathrm{C}, 60.16, \mathrm{H}, 4.26 ; \mathrm{N}, 11.11$.

2-Amino-4-oxo-4-(1-oxo-4-(3-chloro-4methylphenyl)phthalazin-2(1H)-yl)butanoic acid (10b)

Yield $84 \%$ as white crystals. Mp 232-234 ${ }^{0} \mathrm{C}$. IR (KBr) $v \mathrm{~cm}^{-1}: 1751,1658(\mathrm{CO}) .{ }^{1} \mathrm{H}-\mathrm{NMR}$ (DMSO-d6) $\delta$ ppm at: $\delta 2.33\left(\mathrm{~m}, 3 \mathrm{H}, \mathrm{CH}_{3}\right)$, 3.46-3.49(2dd, 2H, $\left.\mathrm{CH}_{2} \mathrm{CO}\right), 4.67(\mathrm{dd}, 1 \mathrm{H}, \mathrm{CH})$, 5.6(bs, 2H, $\left.\mathrm{NH}_{2}\right), 7.33-8.28(\mathrm{~m}, 7 \mathrm{H}, \mathrm{Ar}-\mathrm{H})$, 8.3(s, $1 \mathrm{H}, \mathrm{COOH}) .{ }^{13} \mathrm{C} \mathrm{NMR}\left(\mathrm{CDCl}_{3}\right) \delta \mathrm{ppm}$ : 33.6, 53.8 (N-CH2), 20.6,53.3, 127.2, 127.5, $127.6,129.2,129.3,130.5,130.9,132.2,132.3 .1$ 33.3.134.7.134.5,138.3,158.0 $(\mathrm{C}=\mathrm{N}), 174.9(\mathrm{C}=\mathrm{O})$ and $1752(\mathrm{C}=\mathrm{O})$ Anal. (M.wt. 385) \% Anal. Calc for $\mathrm{C}_{19} \mathrm{H}_{16} \mathrm{~N}_{3} \mathrm{O}_{4} \mathrm{Cl}(385)$ : $\mathrm{C}, 59.22 ; \mathrm{H}, 4.51 ; \mathrm{N}$, 10.52 ; found $\mathrm{C}, 58.63, \mathrm{H}, 4.27$; N, 10.09.

2-Amino-5-oxo-5-(1-oxo-4-(3-chloro-4-methylphenyl) phthalazin-2(1H)-yl)pentanoic acid (10c)

Yield $84 \%$ as white crystals. Mp $226-228{ }^{\circ} \mathrm{C}$. IR (KBr) $v \mathrm{~cm}^{-1}:$ 1751, 1658(CO). ${ }^{1} \mathrm{H}-\mathrm{NMR}$ (DMSO-d6) $\delta$ ppm at: $\delta 2.35\left(\mathrm{~m}, 3 \mathrm{H}, \mathrm{CH}_{3}\right), 2.1\left(\mathrm{~m}, 2 \mathrm{H}, \mathrm{CH}_{2}\right)$, 2.94(t, 2H, $\left.\mathrm{CH}_{2} \mathrm{CO}\right), 4.62(\mathrm{~s}, 1 \mathrm{H}, \mathrm{CH}), 5.6\left(\mathrm{bs}, 2 \mathrm{H}, \mathrm{NH}_{2}\right)$, 7.33-8.28 (m, 7H, Ar-H ), 8.3(s, 1H, COOH). ${ }^{13} \mathrm{C}$ NMR $\left(\mathrm{CDCl}_{3}\right) \delta$ ppm: 20.5, 36.4, 127.2, 127.2, 127.6, 129.2, $129.3,130.5,131.2,131.3,130.6,132.3,134.7,134.5$, 138.3, $158.0(\mathrm{C}=\mathrm{N}), 174.5(\mathrm{C}=\mathrm{O})$ and $175.2(\mathrm{C}=\mathrm{O})$. Anal. Calc for $\mathrm{C}_{20} \mathrm{H}_{18} \mathrm{~N}_{3} \mathrm{O}_{4} \mathrm{Cl}(405.45) \%$ : C ,60.15; $\mathrm{H}$ ,4.51; N, 10.52 ; found C ,59.86, H, 4.25; N, 10.9 .

Synthesis of Arylidine derivatives 11

A mixture of hydrazide $3(3.87 \mathrm{~g}, 0.01 \mathrm{~mol})$, appropriate aromaticaldehyde $(0.01 \mathrm{~mol})$ namely3,4-dichlorobenzaldehyde and 4-dimethylaminobenzaldehyde was refluxed in absolute ethanol $(30 \mathrm{~mL})$ and few drops acetic acid for 9h. After cooling, the separated solid was collected by filtration, dried and crystallized from proper solvent.

$N$-(4-Dimethylamino)benzylidene)-2-(3-chloro-4methylphenyl)phthalazine-2(1H)-acetohydrazide(11a

Yield 96\%, white crystals crystallized from benzene. Mp 184-186 C. IR $(\mathrm{KBr}) v \mathrm{~cm}^{-1}: 1620(\mathrm{C}=\mathrm{N})$, $1673(\mathrm{CO})$ and $3170(\mathrm{NH}) .{ }^{1} \mathrm{H}-\mathrm{NMR}$ (DMSO-d6) $\delta \mathrm{ppm}$ at: $\delta 2.29\left(\mathrm{~m}, 3 \mathrm{H}, \mathrm{CH}_{3}\right), 2.7\left(\mathrm{~s}, 6 \mathrm{H}, \mathrm{N}\left(\mathrm{CH}_{3}\right)_{2}\right), 4.01(\mathrm{~s}$, $2 \mathrm{H}$, methylene proton), 6.7(s, $1 \mathrm{H}, \mathrm{CH}=), 7.11-8.21$ $(\mathrm{m}, 11 \mathrm{H}, \mathrm{Ar}-\mathrm{H}), 12.04(\mathrm{~s}, 1 \mathrm{H}, \mathrm{NH}$ exchangeable with $\left.\mathrm{D}_{2} \mathrm{O}\right) .{ }^{13} \mathrm{C} \mathrm{NMR}\left(\mathrm{CDCl}_{3}\right) \delta$ ppm: 35.9 (methyl of Ar), 56.2(2methyl of $\left.\mathrm{N}\left(\mathrm{CH}_{3}\right)_{2}\right), 64.2$ (methylene $\left.\mathrm{N}-\mathrm{CH}_{2}\right), 122.4,126.9,127.2,127.7,128.4,128.7$,
$129.7,129.9,130.6,130.6,131.5,132.8,133.9$, $134.8,136.2,160.6,168.4,166.5,167.2,168.2$, $169.0(\mathrm{C}=\mathrm{N}, \mathrm{C}=\mathrm{O})$. MS: $\mathrm{m} / \mathrm{z}=472$, 470. Anal. Calc. for $\mathrm{C}_{27} \mathrm{H}_{23} \mathrm{~N}_{7} \mathrm{O}_{2} \mathrm{Cl}(512) \% \mathrm{C}, 63.28 ; \mathrm{H}, 4.49$; $\mathrm{N}, 19.14$; found: C ,62.88; H, 4.29; N , 19.05

$N^{-}$-(4-Chlorobenzylidene)-2-(4-(3-chloro-4methylphenyl)phthalazine-2(1H)-acetohydrazide (11b)

Yield 98\%, orange crystals crystallized from benzene. Mp $224-226^{\circ} \mathrm{C}$. IR(KBr) $v\left(\mathrm{~cm}^{-1}\right)$ $1604(\mathrm{C}=\mathrm{N}), 1666(\mathrm{CO})$ and $3170(\mathrm{NH}) .{ }^{1} \mathrm{H}-\mathrm{NMR}$ (DMSO-d6) $\delta$ ppm at: $1.8\left(\mathrm{~m}, 3 \mathrm{H}, \mathrm{CH}_{3}\right), 4.51(\mathrm{~s}$, $2 \mathrm{H}$, methylene proton), $6.7(\mathrm{~s}, 1 \mathrm{H}, \mathrm{CH}=), 7.11-8.21$ (m, 10H, Ar-H), 12.04(s, 1H, NH exchangeable with $\left.\mathrm{D}_{2} \mathrm{O}\right) \cdot{ }^{13} \mathrm{C} \mathrm{NMR}\left(\mathrm{CDCl}_{3}\right) \delta \mathrm{ppm}$ : 35.9( methyl of $\mathrm{Ar}$ ), 55.4, 62.2 (methylene $\mathrm{N}-\mathrm{CH}_{2}$ ), 122.2, $122.8,124.2,124.7,126.4,126.5,127.0,127.5$, $129.1,129.2,129.6,132.6,134.7,134.9,136.2$, 143.2, 148.6, 155.4, 156.5, 167.9, 174.2, 174.0 $(\mathrm{C}=\mathrm{N}, \mathrm{C}=\mathrm{O})$. $\mathrm{MS}: \mathrm{m} / \mathrm{z}=472$, 470. Anal. Calc. for $\mathrm{C}_{26} \mathrm{H}_{17} \mathrm{~N}_{4} \mathrm{OCl}_{3}(496)$ : $\mathrm{C}, 60.48 ; \mathrm{H}, 3.42 \mathrm{~N}, 8.46$ found: C, 60.21; H, 3.36; N ,8.39.

(E)-N-(2-(2-Aminophenylthio)-5-nitrobenzylidene)-2(4-(3-chloro-4-methylphenyl) phthalazin-2 (1H)-yl) acetohydrazide (12)

A mixture of hydrazide $3(3.87 \mathrm{~g}, 0.01 \mathrm{~mol})$, 4-nitro2-(2-aminothiophenyl)benzaldehyde was refluxed in absolute ethanol $(30 \mathrm{~mL})$ and few drops acetic acid for $9 \mathrm{~h}$. After cooling, the separated solid was washed with light petrol(b.p $40-60^{\circ} \mathrm{C}$ ), collected by filtration, dried and crystallized from benzene. Yield $90 \%$, green crystals. Mp 240 (NH2)3420,(3345-3100), 1658 (CO) and 30903100(NH), 3345-3420( $\left.\mathrm{NH}_{2}\right)$. ${ }^{1} \mathrm{H}-\mathrm{NMR}$ (DMSO-d6) $\delta$ ppm at: $1.8\left(\mathrm{~m}, 3 \mathrm{H}, \mathrm{CH}_{3}\right), 4.21(\mathrm{~s}, 1 \mathrm{H}, \mathrm{CH}), 6.98-8.20$ $(\mathrm{m}, 14 \mathrm{H}, \mathrm{Ar}-\mathrm{H}), 10.04(\mathrm{~s}, 1 \mathrm{H}, \mathrm{NH}$ exchangeable with $\left.\mathrm{D}_{2} \mathrm{O}\right) \cdot{ }^{13} \mathrm{C} \mathrm{NMR}\left(\mathrm{CDCl}_{3}\right) \delta \mathrm{ppm}$ : 35.9( methyl of $\mathrm{Ar}$ ), 64.2 (methylene $\left.\mathrm{N}-\mathrm{CH}_{2}\right), 85.7(\mathrm{~S}-\mathrm{CH})$, $122.3,126.4,127.5,127.9,128.0,128.1,128.6$, $129.0,129.4,129.5,129.6,130.2,130.8,131.3$, $131.5,132.7,134.3,138.1,139.4,140.3,143.6$, $160.7,165.4,165.6,166.3,167.9,168.7(\mathrm{C}=\mathrm{N}$, $\mathrm{C}=\mathrm{O}$ ). Anal. Calc. for $\mathrm{C}_{30} \mathrm{H}_{19} \mathrm{~N}_{6} \mathrm{O}_{3} \mathrm{SCl}(590.69)$ : $\mathrm{C}$, 62.60; H, 3.82; N ,14.60; S, 5.56; found: C, 61.96; H, 5.38; N, 14.17; S, 5.37.

2-[4-(3-Chloro-4-methylphenyl)-1-oxo-2Hphthalzin-2-yl]-N-(1,3-dioxo-1,3-dihydroisoindol-2-yl) acetamide (13)

A mixture of hydrazide $3(3.87 \mathrm{~g}, 0.01 \mathrm{~mol})$, phthalic anhydride $(1.4 \mathrm{~g}, 0.01 \mathrm{~mol})$ was heated in an oil bath at $180^{\circ} \mathrm{C}$ for $1 \mathrm{~h}$. The fused mixture was then treated with ethanol and filtered. The 
crude product was crystallized from dioxane. Yield 92\%, white crystals. Mp $268-270^{\circ} \mathrm{C}$. IR(KBr) $v\left(\mathrm{~cm}^{-1}\right) 1650,1690,1735,1790(4 \mathrm{CO})$. ${ }^{1} \mathrm{H}-\mathrm{NMR}$ (DMSO-d6) $\delta \mathrm{ppm}$ at: $2.32(\mathrm{~m}, 3 \mathrm{H}$, $\mathrm{CH}_{3}$ ), 4.20(s, 1H, CH of gly. precusor), 7.26-8.11 $(\mathrm{m}, 11 \mathrm{H}, \mathrm{Ar}-\mathrm{H}), 9.11(\mathrm{~s}, 1 \mathrm{H}, \mathrm{NH}$ exchangeable with $\left.\mathrm{D}_{2} \mathrm{O}\right) \cdot{ }^{13} \mathrm{C} \mathrm{NMR}\left(\mathrm{CDCl}_{3}\right) \delta$ ppm: 38.3-47.8 (methylene groups), 47.6 (methylene $\mathrm{N}-\mathrm{CH}_{2}$ ), $124.5,126.3,127.5,128.3,128.8,128.9,130.2$, $130.3,131.6,131.9,132.8,132.9,133.8,133.9$, $138.5,139.3,143.4,145.7,158.7,160.2,164.3$, 168.5, $170.3(\mathrm{C}=\mathrm{N}, 3 \mathrm{C}=\mathrm{O})$. Ms: $m / z$ 472, 470, Anal. Calc. for $\mathrm{C}_{25} \mathrm{H}_{17} \mathrm{~N}_{4} \mathrm{O}_{4} \mathrm{Cl}_{1}$ (435) $\mathrm{C}$ 68.96, $\mathrm{H}$ 3.21, N 12.87, found: C 69.07, H 2.94, N 12.65.

N-(2-Oxoindolin-3-ylidene)-2-(4-(3-chloro4-methylphenyl) phthalazin-2(1H)-yl) acetohydrazide (14)

A mixture of hydrazide $3(3.87 \mathrm{~g}, 0.01 \mathrm{~mol})$, isatin $(1.4 \mathrm{~g}, 0.01 \mathrm{~mol})$ and few drops of acetic acid in ethanol $(20 \mathrm{~mL})$ was refluxed $10 \mathrm{~h}$. After cooling, the obtained solid was collected and filtered. The crude product was crystallized from ethanol. Yield 96\%, white crystals. Mp 218$220^{\circ} \mathrm{C}$. IR(KBr) $v\left(\mathrm{~cm}^{-1}\right) 1660,1670,1705(3 \mathrm{CO})$. ${ }^{1} \mathrm{H}-\mathrm{NMR}$ (DMSO-d6) $\delta \mathrm{ppm}$ at: 1.8 ( $\mathrm{m}, 4 \mathrm{H}$, $\beta$-methylene group ), 4.06(s, $2 \mathrm{H}$, methylene proton of gly. precusor), 7.19-8.25 (m, 11H, Ar-H), 9.8 and $11.7(\mathrm{~s}, 2 \mathrm{H}, 2 \mathrm{NH}$ exchangeable with $\left.\mathrm{D}_{2} \mathrm{O}\right) .{ }^{13} \mathrm{C}$ NMR $\left(\mathrm{CDCl}_{3}\right) \delta$ ppm: 41.1-47.4 (methylene groups), 55.7 (methylene $\mathrm{N}-\mathrm{CH}_{2}$ ), $126.9,127.7,128.7,129.1,129.5,129.8,130.1$, $130.6,131.2,131.7,132.5,133.9,134.2,134.5$, $138.2,139.4,140.3,143.5,145.6,158.7,162.1$, 165.7, 168.4(C=N, 2C=O). Ms: $m / z$ 473, 471 . Anal. Calc. for $\mathrm{C}_{25} \mathrm{H}_{18} \mathrm{~N}_{5} \mathrm{O}_{3} \mathrm{Cl}(471)$ : C, 63.69; $\mathrm{H}$ ,3.82; N, 14.86; found: C ,63.18; H 3.31; N, 14.02.

2-((1-Oxo-4-(3-chloro-4-methylphenyl) phthalazin-2(1H)-yl)methyl)-9H-benzo[e][1,2,4] triazolo[5,1-b][1,3]thiazin-9-one (15)

A mixture of hydrazide $3(3.87 \mathrm{~g}, 0.01 \mathrm{~mol})$, ethyl-2-thiocyanatobenzoate $(0.01$ mole $)$ was refluxed in absolute ethanol $(30 \mathrm{~mL})$ for $9 \mathrm{~h}$. After cooling, the separated solid was collected by filtration, dried and crystallized from ethanol. Yield 96\%, white crystals. Mp $184-186^{\circ} \mathrm{C}$. IR $(\mathrm{KBr}) \vee \mathrm{cm}^{-1} 1620(\mathrm{C}=\mathrm{N}), 1673(\mathrm{CO})$ and 3170(NH). ${ }^{1} \mathrm{H}-\mathrm{NMR}(\mathrm{DMSO}-d 6) \delta \mathrm{ppm}$ at: 1.8 $\left(\mathrm{m}, 3 \mathrm{H}, \mathrm{CH}_{3}\right), 4.01(\mathrm{~s}, 2 \mathrm{H}$, methylene proton of gly. precusor), 7.11-8.21 (m, $11 \mathrm{H}, \mathrm{Ar}-\mathrm{H}) \cdot{ }^{13} \mathrm{C}$ NMR $\left(\mathrm{CDCl}_{3}\right) \delta$ ppm: 35.9 (methyl of Ar), 64.2 (methylene $\mathrm{N}-\mathrm{CH}_{2}$ ), 122.4, 126.9, 127.2, 127.7, 128.4, 128.7, 129.0, 129.5, 130.1, 130.6, 131.2,

Egypt.J.Chem. 60 , No.3 (2017)
$132.5,133.9,134.5,138.2,143.5,160.6,165.4$, 166.5, 167.2, 168.2, $169.0(\mathrm{C}=\mathrm{N}, \mathrm{C}=\mathrm{O}) . \mathrm{Ms}: \mathrm{m} / \mathrm{z}$ 487.5, 485.5. Anal. Calc. for $\mathrm{C}_{25} \mathrm{H}_{16} \mathrm{~N}_{5} \mathrm{O}_{2} \mathrm{SCl}$ (475): C, 61.85; H,3.29; N,14.43; S,6.59; found: $\mathrm{C}, 61.32 ; \mathrm{H}, 3.01 ; \mathrm{N}, 14.130 ; \mathrm{S}, 6.48$.

4-(3-Chloro-4-methylphenyl)-2-((2S,3R,4R,5S,6R)-3,4,5trihydroxy-6-(hydroxymethyl)tetrahydro-2H-pyran-2ylamino)-1,3,4thiadiazol-2-yl)methyl)phthalazin1(2H)one(16)

In one pot reaction of a mixture of hydrazide $(0.774 \mathrm{~g}, \quad 0.002 \mathrm{~mol}), \mathrm{D}(+)$ glucosyl bromide $(0.34 \mathrm{~g}$; $0.002 \mathrm{~mol})$, ammonium isocyanate $(0.03 \mathrm{~mol})$ in pyridine $(20 \mathrm{~mL})$ was refluxed for $6 \mathrm{~h}$. After cooling, the reaction mixture poured onto ice $/ \mathrm{H}_{2} \mathrm{O}$. The solid that formed was filtered off, dried and crystallized from ethanol. Yield $86 \%$, colourless crystals. Mp $290-292^{\circ} \mathrm{C}$. IR(KBr) $v \mathrm{~cm}^{-1} 1650(\mathrm{CO}), 3233(\mathrm{NH}), 3440(\mathrm{OH})$. ${ }^{1} \mathrm{H}-\mathrm{NMR}$ (DMSO-d6) $\delta \mathrm{ppm}$ at: $\delta 1.8\left(\mathrm{~m}, 3 \mathrm{H}, \mathrm{CH}_{3}\right)$, $2.12-2.62(\mathrm{~m}, 7 \mathrm{H}, \mathrm{H}$ of glucose moiety), 4.20(s, $2 \mathrm{H}$, methylene protons), 4.60(bs, 4H, OHglu), 6.9-7.8 (m, $7 \mathrm{H}, \mathrm{Ar}-\mathrm{H}), 9.80\left(\mathrm{~s}, 1 \mathrm{H}, \mathrm{NH}\right.$ exchangeable with $\left.\mathrm{D}_{2} \mathrm{O}\right)$. ${ }^{13} \mathrm{C}$ NMR $\left(\mathrm{CDCl}_{3}\right) \delta$ ppm: 39.45- 46.5 (methylene groups of Ar), 52.8(methylene), 122.3, 125.7, 126.9, $127.7,128.7,129.1,130.2,131.7,132.5,133.9,134.2$, $134.5,136.5,138.2,139.4,140.2,143.5,145.6,158.7$, 160.6, 165.4, $168.2(3 \mathrm{C}=\mathrm{N}, \mathrm{C}=\mathrm{O})$. Anal. Calc. for $\mathrm{C}_{24} \mathrm{H}_{24} \mathrm{~N}_{5} \mathrm{O}_{6} \mathrm{~S} \mathrm{Cl}(530) \% \mathrm{C}, 54.33 ; \mathrm{H}, 4.71 ; \mathrm{N}, 13.20$; S; 6.03 found \% C , 53.95; H, 4.12; N, 13.08 ;S, 5,89

\section{References}

1. Jain, R.P. and Vederas, J.C. Structural variations in keto-glutamines for improved inhibition against hepatitis A virus $3 \mathrm{C}$ proteinase. Bioorg. Med. Chem. Lett., 14, 3655 (2004). B) Xu, Y., Guo, Q; syntheses of heterocyclic compounds under microwave irradiation. Heterocycl 63, 903 (2004). C) Strappaghetti, G., Brodi, C., Giannaccini, G., Betti, L.; New 4-(4-methyl-phenyl) phthalazin-1(2H)-one derivatives and their effects on $\alpha 1$-receptors. Bioorg. Med. Chem. Lett. 16, 2575(2006). D) Gribble, G. W. In Comprehensive Heterocyclic C v max hemistry II; Katrizky. A.R., Rees, C.W. Scriven, E. V.,Eds.; Comprehensive Heterocyclic Chemistry III, 15-Volume Set Elsevier: Oxford, 2, 207(1996).

2. El-Shamy I.E., Abdel-Mohsen A.M., Alsheikh A.A., Fouda M. G., Al-Deyab S.S. , El-Hashash M.A. , Jancar J., Synthesis, biological, antiinflammatory activities and quantum chemical calculation of some [4-(2, 4, 6-trimethylphenyl)1(2H)-oxo-phthalazin-2yl] acetic acid hydrazide derivatives.Dyes and Pigments 113, 357 (2015).

3. Wagdy M.E., Hany S.I., Hatem A.A., Noha N.F., Mohieldin M.Y., Design, 
synthesis and in vitro antitumor activity of novel N-substituted-4-phenyl/benzylphthalazin1-onesEuro. J. Med. Chem., 89 549(2015).

4. Alo-Asser, F., Zelenin, K.N., Lesiovskaya, E.E., Bezhan, I.P., Chakchir, B.A. Synthesis and pharmacological activity of 1-hydroxy-, 1-amino-, and 1-hydrazino-substituted 2,3-dihydro-1hpyrazolo[1,2-a]pyridazine-5,8-diones and 2,3-dihydro-1h-pyrazolo[1,2-b] phthalazine5,10-diones. Pharm. Chem. J. 36, 598 (2002).

5. Jain, R.P., Vederas, J.C., Structural variations in keto-glutamines for improved inhibition against hepatitis A virus 3C proteinase. Bioorg.Med.Chem.Lett. $14 \quad, \quad 3655 \quad$ (2004).

6. Carling, R.W., Moore, K.W., Street, L.I., Wild, D., Isted, C., Leeson, P. D., Thomas, S., O-Conner, D., Mc-Kernan, R.M., Quirk, K., Cook, S.M., Atack, J.R., Waftord, K.A., Thompson, S.A. Dawson , G.R.; Ferris, P. Castro, J.I. 3-Phenyl6-(2-pyridyl)methyloxy-1,2,4-triazolo[3,4-a] phthalazines and analogues: high-affinity $\gamma$-aminobutyric acid-a benzodiazepine receptor ligands with $\alpha 2, \alpha 3$, and $\alpha 5$-subtype binding selectivity over $\alpha 1 . J$. Med. Chem. 47, 1807(2004).

7. Grasso, S., De-Sarro, G., Micale, N., Zappala, M., Puia, G., Baraldi, M., Demicheli, C. Synthesis and anticonvulsant activity of novel and potent 6,7-methylenedioxyphthalazin1(2h)-ones. J. Med. Chem. 43, 2851(2000).

8. Haikal, A., El-Ashry, E., Banoub, J., Synthesis and structural characterization of 1-(D-glycosyloxy) phthalazines. Carbohydr. Res., 338, 2291(2003). B) Kim, J.S., Lee, H., Suh, M., Choo, H. P., Lee, S.K., Park,H.J.; Synthesis and cytotoxicity of 1-substituted 2-methyl-1H-imidazo[4,5-g]phthalazine-4,9-dione derivatives.Bioorg. Med. Chem. 12, 3683(2004).

9. Demirayak, S., Karaburun, A., Beis, R., Some pyrrole substituted aryl pyridazinone and phthalazinone derivatives and their antihypertensive activities. Eur. J. Med. Chem. 39, 1089(2003).

10.Johsen, M., Rehse, K., Petz, H., Stasch, J., Bischoff, E., 3. New antithrombotic 1phthalazinamines with serotonin antagonistic properties.Arch. Pharmacol. 336, 591(2003).

11. Lenz, E., Wilson, I., Wright, B., Partidge, E., Roddgers, C., Haycock, P.R., A comparison of quantitative NMR and radiolabelling studies of the metabolism and excretion of Statil (3-(4-bromo-
2-fluorobenzyl)-4-oxo-3H-phthalazin-1-ylacetic acid) in the rat. Pharm. Biomed. Anal. 28, 31(2002).

12. Olmo, E., Armas, M., Lopez-perez, J., Ruiz, G., Vagas, F., Gimenez, A., Anti-Trypanosoma activity of some natural stilbenoids and synthetic related heterocyclic compounds. Bioorg. Med. Chem. Lett. 11, 2755(2001)

13.Dogruer, D., Kupeli, E., Yesilada, E., Sahin, M., Synthesis of new 2-[1(2h)phthalazinon-2-yl]acetamide and 3-[1(2h)phthalazinon-2-yl]propanamide derivatives as antinociceptive and anti-inflammatory agents. Arch. Pharmacol. 337, 303(2004).

14. Nomoto, Y., Obase, H., Takai, H., Teranishi, M., Nakamura, J., Kubo, K. Studies on cardiotonic agents. Ii. : Synthesis of novel phthalazine and 1, 2, 3-benzotriazine derivatives. Chem. Pharm. Bull. 38, 2179(1990).

15.Watanable, N., Kabasawa, Y., Takase, Y., Matsukura, M., Mivazaki, K., Ishihara, H., Kodama, K., Adachi, H. 4-Benzylamino-1-chloro-6-substituted phthalazines: synthesisandinhibitoryactivitytoward phosphodiesterase 5.J. Med. Chem. 41, 3367(1998).

16. Sheradsky, T., Moshenberg, R. Bridgehead hydrazines. 3. Unusual photorearrangement of 1,4-diphenylpyridazino [1,2-b] phthalazine6,11-dione J. Org. Chem. 51, 3123(1986).

17. Heine, H.W., Baclawski, L.M., Bonser, S.M., Wachob, G.D. Diaziridines. 5. Reaction of some 1-aroyl- and 1,2-diacyldiaziridines. J. Org. Chem. 41, 3229 (1976).

18. Ramtohup, Y.K., James, M.N.G., Vederas, J.C. Synthesis and evaluation of keto-glutamine analogues as inhibitors of hepatitis a virus $3 \mathrm{c}$ proteinase. J. Org. Chem. 67, 3169 (2002).

19. Lui, L.P., Lu, J.M., Shi, M. PhI (OAc) 2-Mediated Novel 1,3-Dipolar Cycloaddition of Methylenecyclopropanes (MCPs), Vinylidenecyclopropanes (VCPs), and Methylenecyclobutane (MCB) with Phthalhydrazide. Org. Lett. 9, 1303(2007).

20. Csampai, A., Kormendy, K., Ruff. F., Chain length dependent reactivity of 2-( $\omega$-hydroxyalkyl)-4-( $\omega$-hydroxyalkylamino) phthalazin-1(2h)-ones in azeotropic

Egypt.J.Chem. 60 , No.3 (2017) 
hydrobromic acid. Tetrahedron 47, 4457(1991) .

21.Amarasekara, A.S., Chandrasekara, S., Reaction of 1,4-phthalazinedione with furfural: formation of the $[5,6]$ benza-3a,7a-diazaindane system via an unusual skeletal rearrangement. Org. Lett. 4, 773(2002).

22. Hwang, J.Y., Choi, H.S., Gong Y.D. Solidphase synthesis of $[1,2,4]$ triazolo $[3,4-a]$ phthalazine and tetrazolo[5,1-a]phthalazine derivatives.Tetrahedron Lett. 46, 3107(2005).

23. Berard N.; Hay A.S., Monomer reactivity ratios of styrene-4-vinylpyridine copolymers at low and high conversions.Polym.Prepr. (Am. Chem. Soc. Div. Polym. Chem). 34, 148(1993).

24. Meng Y.Z., Jian X.G., Hay A.S., Preparation and performance of SPPES/PPES hollow fiber composite nanofiltration membrane with high temperature resistance. Chin. Polym. Mater. Sci. Eng., 10(6), 34(1994).

25. Jian X.G., Meng Y.Z., Zheng H.B., preparation of poly phthalazinone ether sulfone. Chinese Patent 93109180.2, (1993a)

26. Jian X.G.; Meng Y.Z., Zheng H.B., preparation of poly phthalazinone ether ketone .Chinese Patent 93109179.9, (1993b)

27. Jian, X.G.; Dai, Y.; Zheng, L.; Xu, R.X., Application of poly- (phthalazinone ether sulfone ketone)s to gas membrane separation J. Appl. Polym. Sci., 71, 2385(1999).

28. Tarab S., Turkustani A.M., Corrosion inhibition of steelphosphoricacidby phenacyldimethylsulfonium Bromide and some of its p-substituted derivatives. Portugaliae Electrochimica Acta. 24, 253 (2006).

29. Eddy N.O., Ebenso E.E., Corrosion inhibition and adsorption properties of ethanol extract of Gongronema latifolium on mild steel in H2SO4. Pigment and Resin Tech. 39, 77(2010).

30. Sangeetha, M., Rajendran, S., Muthumegala, T.S., Krishnaveni, A., Green corrosion inhibitors - An Overview. Zaštita Materijala, 52: 3-19(2011). B) Umoren S.A., Obot I.B., Obi-Egbedi N.O.; Raphia hookeri gum as a potential eco-friendly inhibitor for mild steel in sulfuric Acid..Mater. Sci. 44 (1), 274(2009).
31. Fouda, A.S., Nazeer, A., Ashour, E. A., Amino acids as environmentally-friendly corrosion inhibitors for Cu10Ni alloy in sulfide-polluted salt water: Experimental and theoretical study. Zaštita Materijala. 52, 21(2011). B) Obot I.B., Obiegbedi N.O.; Surface Review and Letters. 15(6), 903(2008).

32. Saji, V.S., A Review on Recent Patents in Corrosion Inhibitors. Recent Patents on Corrosion Science 2, 6(2010) B) Obot I.B., Obi-Egbedi N.O., Fluconazole as an inhibitor for aluminium corrosion in $0.1 \mathrm{M} \mathrm{HCl}$. Collid Surface, Physicochem. Eng. Aspects 330, 207(2008).

33. Ju H, Kai Z.P., Li Y., Aminic nitrogen-bearing polydentate Schiff base compounds as corrosion inhibitors for iron in acidic media: A quantum chemical calculation. Corros. Sci. 50, 865 (2008).

34. N.O. Eddy, S.A, Odoemelam and A.O. Odiongenyi.; Ethanol Extract of Musa acuminate peel as an ecofriendly inhibitor for the corrosion of $\mathrm{m} 24$ ild steel in $\mathrm{H} \mathrm{SO}_{4}$. Adv. Nat. Appl. Sci. 2 (1), 35(2008).

35. Umoren S.A., Obot I.B., Ebenso E.E., ObiEgbedi N.O., Synergistic inhibition between naturally occurring exudate gum and halide ions on the corrosion of mild steel in acidic medium . Int. J. Electrochem. Sci. 3, 1029(2008).

36. Abdel-Rhim S.S., Ibrahim M.A., Khaled F.F., 4-Aminoantipyrine as an inhibitor of mild steel corrosion in $\mathrm{HCl}$ solution Appl. Electrochem. 29, 593(1999).

37. Wang H.L., Lui R.B., Xin J., Inhibiting effects of some mercapto-triazole derivatives on the corrosion of mild steel in $1.0 \mathrm{M}$ HC1 medium .Corros. Sci. 46, 2455(2004).

38. Ebenso E.E., Effect of halide ions on the corrosion inhibition of mild steel in H2SO4 using methyl red. Bull. Electrochem.2003, 19, 209. B) Khalil N.; Quantum chemical approach of corrosion inhibition. Electrochim. Acta. 48, 2635(2003).

39. Trabanelli G.F. Mansfeld (Ed), Corros. Mech., Marcel Dekker, New York. p.119 (1987).

40. Schultze J.W., WippermannK., Inhibition ofelectrode processes on copper by AHT in acid solutions. Electrochim. Acta 32, 823 (1987). B) El-Rahman H.A.; Evaluation of AHT as corrosion inhibitor for $\alpha$-brass in acid chloride solutions. Corros. 47, 
424 (1991). C) Quartarone G., Bellomi T., Zingales A.; Inhibition of copper corrosion by isatin in aerated 0.5 M H2SO4. Corros. Sci. 45, 715 (2003).

41. El-Hashash M.A., Guirguis D.B., Kadhim M.A., Synthesis of novel series of phthalazine derivatives with antibacterial and antifungal evaluation. J. American Science 9 ,12(2013).

42. Perigaud, C., Gosselin, G., Imbach, J.L., Nucleoside analogues as chemotherapeutic agent. Nucleotides. 11, $903 \quad$ (1992).

43. Chu, C.K.; Cutler, S.J., Chemistry and antiviral activities of acyclonucleoside. J. Heterocycl. Chem. 23, 289 (1986).

44. Remy, R.J., Secrist J.A. Acyclic Nucleosides other than acyclovir as potential antiviral agents. Nucleotides. 4, 411(1985).

45. Balzarini, J., De-Clereq, E. Synthesis of Nucleoside Phosphate and Phosphonate Prodrugs. Pharmacochem.Libr. 14, 175(1990). B) Chu C.K.; Baker D.C. Nucleosides Nucleotides as Antitumer and Antiviral Agents: Plenum Press: New York (1993) C) De Clereq. E. Int. J. Immuno-pharmacol. 13, 91(1991).

46. Kim H.O., Shanmuganathan. K., Alves A.J., Jeong L.S., Beach J.W., Shinazi, R.F., Chang, C.N., Cheng, Y.C., Chu, C.K., Potent anti-HIV and anti-HBV activities of (-)-L-B-Dioxolane-C and $(+)$-D-B-Dioxolane-T and their asymmetric syntheses. Tetrahedron Lett. 33, 6899 (1992).

47. Wang, C.C., Current problems in anti-parasite chemotherapy.Trends Biochem.Sci. 7, 354 (1982).

48. Mittelman, A., Evans, J.T., Chheda, G.B., Ann, N.Y., Cytokininsaschemotherapeuticagents.Acad.Sci.255(1975).

49. Hashizuma, T., Yoshida, K., Characterization and Some Cultural Conditions of a Cyclodextrin Glycosyltransferase-producing Alkalophilic Bacillus sp. Agr. Biol. Chem. 40, 2001(1976).

50. Shibata, H., Ohnishi, N., Takeda, K., Fukunaga, H., Shimamura, K., Yasunobu, E., Tani, I., Germination of Bacillus cereus spores induced by purine ribosides and their analogs: effects of modification of base and sugar moieties of purine nucleosides on germination-inducing activity. Can. J. Microbiol. 32, 186(1986).
51. El-Hashash, M.A., Rizk, S.A., Atta-Alla, S.R., One-pot synthesis of novel spirooxindoles as antibacterial and antioxidant agents: multi-component reaction (MCR) Molecules. 20, 22069 (2015).

52. El-Hashash, M.A., Rizk S.A., Regioselective diastereotopic michael reaction as building blocks in heterocyclic synthesis. J. Hetrocycl. Chem. 54, 864 (2017).

(Received 13/4/2017;

Accepted 24/5/2017) 
التركيب التجميعي و الخصائص الهيكلية لبعض المشتقات الفثالازينية المضادة للميكروباتو الصبغ التفاعلية

ماهر عبد العزيز الحشاش1 , سامح رزق 1, فخرى البسيونى1, , دلال بسنتى جرجيس1 , شريف محمد خيرى2 وليلى عطية 2

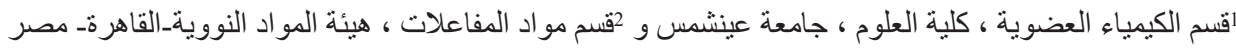

تم توليف سلسلة جديدة من المشتقات من فثالازين1) - (2H)عن طريق عن طريق الاضافة النيوكلوفيلية بذرة النيتروجين

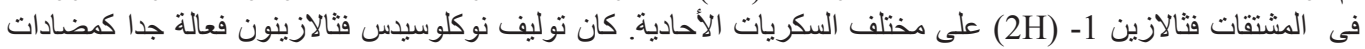

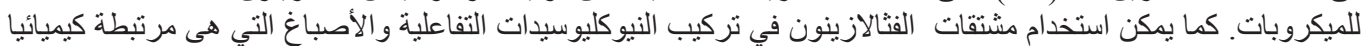

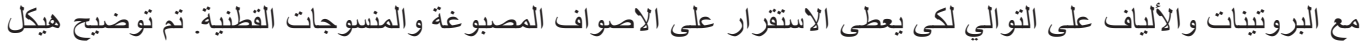

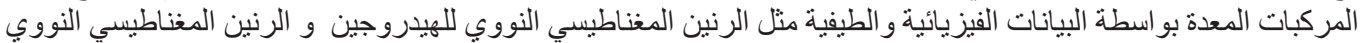

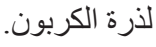

